\title{
33
}

\section{Race Questions and Prejudices}

The numerous questions and prejudices which are aroused by the contact of the various races of men have always been important factors in human history. They promise, however, to become, in the near future, still more important than they have ever been before. Such increased importance of race questions and prejudices, if it comes to pass, will be due not to any change in human nature, and especially not to any increase in the diversity or in the contrasting traits of the races of men themselves, but simply to the greater extent and complexity of the work of civilization. Physically speaking, great masses of men are to-day brought into more frequent and closer contact than was formerly possible, because of the ease with which at present the numerous means of communication can be used, because of the increase of peaceful migrations, and because of the imperial ambitions of several of the world's great peoples. Hence whatever contact, conflict, or mutual influence the races of men have had in the past, we find to-day more ways and places in which men find themselves in the presence of alien races, with whom they have to learn to live in the same social order. When we think of East Indian coolies now present as laborers, side by side with the native negroes, and with white men, in the British West Indies; when we remember the problem of South Africa, as it was impressed upon our minds a few years since, at a moment when Dutchmen and Englishmen fought for the land, while Kaffirs and

[Reprinted from $R Q P$, pp. 3-53.] 
Zulus watched the conflict; when we recall what the recent war between Japan and Russia has already meant for the future of the races of men in the far East; and when, with a few only of such typical instances in mind, we turn back to our own country, and think how many different race-problems confront us,-we then see that the earliest social problem of humanity is also the most recent problem. This is the problem of dealing with the men who seem to us somehow very widely different from ourselves, in physical constitution, in temperament, in all their deeper nature, so that we are tempted to think of them as natural strangers to our souls, while nevertheless we find that they are stubbornly there in our world, and that they are men as much determined to live as we are, and are men who, in turn, find us as incomprehensible as we find them. Of these diverse races, what ones are the superior and what ones are the inferior races? What race or races ought to rule? What ones ought to yield to their natural masters? To which one of these races has God, or nature, or destiny, ordained the rightful and final sovereignty of the earth? Which of these types of men is really the human type? Are they by their presence and their rivalry essentially perilous to one another's interests? And if so, what one amongst them is there whose spread, or whose increase in power or in number, is most perilous to the true cause of civilization? Is it a "yellow peril," or a "black peril," or perhaps, after all, is it not rather some form of "white peril," which most threatens the future of humanity in this day of great struggles and of complex issues? Are all men equal, as the Eighteenth Century theorists insisted? Or if the actual inequality of men in power, in value, in progressiveness, is an obvious fact, then how is this fact related to racial distinctions?

Such are a few of the questions that crowd upon us when we think about the races of men, and about their various relations to civilization. I do not mean, in this brief discussion, to exhaust any of these questions, but I want to call attention to a few principles which seem to me to be serviceable to any one who wants to look at race questions fairly and humanely.

\section{I}

It will be natural for some of my readers to interpose, at this point, the suggestion that the principal guidance in any attempt to answer 
such questions as the foregoing must come from an appeal to the results of the modern scientific study of the races of men. Why speculate and moralize, one may say? Have not the races of men been studied in recent times with elaborate care? What can tell us how to deal with the race-problems, in case we neglect the results of anthropology and of ethnology? And if we consult those sciences, do they not already give us a basis for decision regarding all such matters-a basis which is far more valuable than any chance observations of an amateur can be?

As a fact, if I supposed that, in their present stage of progress, the sciences which deal with man had already attained to exact results regarding the mental and moral differences, prospects, and destinies, of the different stocks of the genus bomo, nobody would be humbler than I should be in accepting, and in trying to use the verdict that would then have been obtained. But I confess that, as a student of ethics and of certain other aspects of our common human nature, I have been a good deal baffled in trying to discover just what the results of science are regarding the true psychological and moral meaning of race-differences. I shall later speak further of some of the difficulties of this scientific aspect of our topic. It is enough to say here that when I consult any of the known Rassentheoretiker for light, I do indeed learn that the concept of race is the key to the comprehension of all history, and that, if you only form a clear idea of the important types of men (types such, for instance, as the marvellous Germanen of Chamberlain's Grundzüge des Neunzebnten Jahrbunderts), you can then determine with exactness precisely who ought to rule and who ought to yield, and can predict the forms of civilization, the Weltanschanumgen, and the other possessions, which will be characteristic of each type of men, so long as that type shall endure. When I observe, however, that the Rassentheoretiker frequently uses his science to support most of his personal prejudices, and is praised by his sympathizers almost equally for his exact knowledge and for his vigorous display of temperament, I begin to wonder whether a science which mainly devotes itself to proving that we ourselves are the salt of the earth, is after all so exact as it aims to be. It is with some modern race-theories, as it is with some forms of international yacht racing. I know nothing about yachting; but whenever any form of the exalted sport of international yachting proves to be definable as a sort of contest in which the foreigner is invariably beaten, I for my part 
take no interest in learning more about the rules of that particular game. And precisely so, when men marshal all the resources of their science to prove that their own race-prejudices are infallible, I can feel no confidence in what they imagine to be the result of science. Much of our modern race-theory reminds me, in its spirit, altogether too much of some of the conversations in the "Jungle Book,"-or of the type of international courtesy expressed in "The Truce of the Bear,"-too much, I say to seem like exact science. Mowgli's remarks addressed to Red Dog may have been good natural history; but scientific Zoölogy does not proceed in that way.

While I deeply respect, then, the actual work of the sciences which deal with man, and while I fully recognize their modern progress, I greatly doubt that these sciences as yet furnish us with the exact results which representative race-theorists sometimes insist upon. Hence I am unable to begin this little study by a mere report of what science has established regarding the mental and moral varieties of men. I must rather make my beginning with a mention of two instances which have recently been much in my mind, and which bear upon the meaning of race prejudices. One of these instances is to-day in everybody's mind.

\section{II}

I refer then, first, to the wonderful lesson that Japan has been teaching us regarding what human energy and devotion have done and can do, and can do also in case of a race that is indeed remote enough from our own. I remember well the Japan of the geography text-books of my childhood, text-books which were even then antiquated enough; but I believed them. Japan was a weird land, according to the old text-books,-a land from which foreigners were excluded, a land where all things were as perverse as possible, where criminals were boiled in oil, where Catholic missionaries had long ago been martyred. Whatever the Japanese were, they were plainly men of the wrong race. Later, however, I learned something of the contemporary history of Japan as it then was. The scene was now, indeed, vastly changed. The Japanese had opened their land; and hereupon, lo! in a magic way, they were imitating, so we heard, all of our European customs. So we next had to alter our own opinion as to their essential nature. 
They became in our eyes a plastic race of wonderful little children, small of stature, quick of wit, light-minded-a folk who took up any suggestion precisely as the playful children often do. They, too, were playing, it seemed, with our whole Western civilization. Plainly, then, they were a race who had no serious life of their own at all. Those of us who disliked them noted that they thus showed an ape-like unsteadiness of conduct. This, then, was their racial characteristic. Those who admired them thought of them as a new sort of pets, to be humored and instructed with all our superior condescension. Well, as time went on, and I grew to manhood, I myself came to know some of these Japanese as students. Hereupon, however, I gradually learned to see such men in a wholly new light. I found them, with all their steadfast courtesy, pleasantly, but impenetrably reserved-keepers of their own counsel, men whose life had, as I soon found, a vast background of opinions and customs that I could not fathom. When, I said, shall I ever see what is behind that Japanese smile? What is in their hearts? With an immovable self-consciousness they resisted every effort to alter, from without, any of their essential ideals. Politely, whenever you pressed them, they declined to admit that any of our Western arts or opinions were equal in value to their own most cherished national ideal treasures. And this they did even at the moment when they were present, most respectfully, as learners. They learned well; but plainly they meant to use this learning for their own purposes. An enthusiastic lady in an American University town was once seeking to draw from a Japanese visitor some admission of the importance of Christianity for the higher civilization of his country. "Confess," she insisted, "confess what a boon our missionaries have brought you in introducing Christianity into your land." "You are right," answered the Japanese, with his usual courteous smile, "you are right; the missionaries in introducing Christianity, have indeed brought us a great good. They have completed the varicty of religions in Japan."

This impenetrable Japanese self-consciousness, this unconquerable polite and obstinate reserve, what did it mean? Well, Mr. Hearn and his kin have now let us know in a literary way something of the true heart of Japan. And the recent war has shown us what Japan meant by imitating our Western ways, and also what ancestral ideals have led her sons to death in battle, and still 
hold the nation so closely knit to their Emperor. Already I have heard some tender souls amongst us say: "It is they who are racially our superiors." Some of us may live to see Japanese customs pervading our land, and all of our professional imitators trying to be Japanese.

Well, I myself am no worshipper of any new fancy or distant civilization, merely because of its temporary prominence. But the true lesson which Japan teaches us to-day is, that it is somewhat hard to find out by looking at the features of a man's face, or at the color of his skin, or even at the reports of travellers who visit his land, what it is of which his race is really capable. Perhaps the Japanese are not of the right race; but we now admit that so long as we judged them merely by their race, and by mere appearances, we were judging them ignorantly, and falsely. This, I say, has been to me a most interesting lesson in the fallibility of some of our race judgments.

\section{III}

So much, then, for one lesson of experience. I have recently been much impressed by another lesson, but by one of a very different character, occurring, so to speak, at the other extremity of the world of modern race-problems. The negro has so far shown none of the great powers of the Japanese. Let us, then, provisionally admit at this stage of our discussion that the negro is in his present backward state as a race, for reasons which are not due merely to circumstances, but which are quite innate in his mental constitution. I shall indeed return to that topic later on. But, for the moment, let that view pass as if it were finally accepted. View the negro, then, for the instant merely as a backward race. But let the race-question here be our own pressing Southern question: How can the white man and the negro, once forced, as they are in our South, to live side by side, best learn to live with a minimum of friction, with a maximum of coöperation? I have long learned from my Southern friends that this end can only be attained by a firm and by a very constant and explicit insistence upon keeping the negro in his proper place, as a social inferior-who, then, as an inferior, should, of course, be treated humanely, but who must first be clearly and unmistakably taught where he belongs. I have observed that the pedagogical methods which my Southern 
friends of late years have found it their duty to use, to this end, are methods such as still keep awake a good deal of very lively and intense irritation in the minds not only of the pupils but also of the teachers. Now irritation, viewed merely in itself, is not an enlightening state of mind. It is, therefore, according to our modern views, not a very pedagogical state of mind. I am myself, for instance, a fairly irritable person, and I am also a teacher. But at the moments when I am irritated I am certainly not just then a good teacher. Is, however, the irritation which seems to be the accompaniment of some of the recent Southern methods of teaching the negro his place an inevitable evil, a wholly necessary accompaniment of the present transition period in the South? Must such increase of race-hatred first come, in order that later, whenever the negro has fully learned his lesson, and aspires no more beyond his station, peace may come? Well, concerning just this matter I lately learned what was to me, in my inexperience, a new lesson. I have had occasion three times, in recent summers, to visit British West Indies, Jamaica, and Trinidad, at a time when few tourists were there. Upon visiting Jamaica I first went round the coast of the island, visiting its various ports. I then went inland, and walked for miles over its admirable country roads. I discussed its condition with men of various occupations. I read some of its official literature. I then consulted with a new interest its history. I watched its negroes in various places, and talked with some of them, too. I have since collected such further information as I had time to collect regarding its life, as various authorities have discussed the topic, and this is the result:-

Jamaica has a population of surely not more than 14,000 or 15,000 whites, mostly English. Its black population considerably exceeds 600,000 . Its mulatto population, of various shades, numbers, at the very least, some 40 ,ooo or 50,00o. Its plantation life, in the days before emancipation, was much sadder and severer, by common account, than ours in the South ever was. Both the period of emanicipation and the immediately following period were of a very discouraging type. In the sixties of the last century there was one very unfortunate insurrection. The economic history of the island has also been in many ways unlucky even to the present day. Here, then, are certainly conditions which in some respects are decidedly such as would seem to tend toward a lasting state of general irritation, such as you might suppose would make 
race-questions acute. Moreover, the population, being a tropical one, has serious moral burdens to contend with of the sort that result from the known influences of such climates upon human character in the men of all races.

And yet, despite all these disadvantages, to-day, whatever the problems of Jamaica, whatever its defects, our own present Southern race-problem in the forms which we know best, simply does not exist. There is no public controversy about social race equality or superiority. Neither a white man nor a white woman feels insecure in moving about freely amongst the black population anywhere on the island. The colony has a Legislative Assembly, although one of extremely limited legislative powers. For the choice to this assembly a suffrage determined only by a decidedly low rate-qualification is free to all who have sufficient property, but is used by only a very small portion of the negro population. The negro is, on the whole, neither painfully obstrusive in his public manners, nor in need of being sharply kept in his place. Within the circles of the black population itself there is meanwhile a decidedly rich social differentiation. There are negroes in government service, negroes in the professions, negroes who are fairly prosperous peasant proprietors, and there are also the poor peasants; there are the thriftless, the poor in the towns,-yes, as in any tropical country, the beggars. In Kingston and in some other towns there is a small class of negroes who are distinctly criminal. On the whole, however, the negroes and colored population, taken in the mass, are orderly, law-abiding, contented, still backward in their education, but apparently advancing. They are generally loyal to the government. The best of them are aspiring, in their own way, and wholesomely self-conscious. Yet there is no doubt whatever that English white men are the essential controllers of the destiny of the country. But these English whites, few as they are, control the country at present, with extraordinarily little friction, and wholly without those painful emotions, those insistent complaints and anxieties, which at present are so prominent in the minds of many of our own Southern brethern. Life in Jamaica is not ideal. The economical aspect of the island is in many ways unsatisfactory. But the negro race-question, in our present American sense of that term, seems to be substantially solved.

How? By race-mixture?

The considerable extent to which race-mixture went in the 
earlier history of Jamaica is generally known. Here, as elsewhere, however, it has been rather the social inequality of the races, than any approach to equality, which has been responsible for the mixture, in so far as such has occurred. It was the social inequality of the plantation days that began the process of mixture. If the oftenmentioned desire to raise the "color" of their children, has later led the colored population to seek a further amalgamation of the two stocks, certainly that tendency, so far as it is effective, has been due to the social advantages of the lighter color-and not due to any motive which has decreased the ancient disadvantages under which the darker race has had to suffer. If race-amalgamation is indeed to be viewed as always an evil, the best way to counteract the growth of that evil must everywhere be the cultivation of racial self-respect and not of racial degradation. As a fact, it is not the amalgamation of the stocks, so far as that has occurred, which has tended to reduce the friction between the races in Jamaica. As to the English newcomers to the island, they probably do not tend to become amalgamated with the colored stocks in Jamaica, more than in any other region where the English live. The English stock tends, here as elsewhere, to be proud of itself, and to keep to itself. How then has the solution of what was once indeed a grave race-question been brought about in Jamaica?

I answer, by the simplest means in the world-the simplest, that is, for Englishmen-viz.: by English administration, and by English reticence. When once the sad period of emanicipation and of subsequent occasional disorder was passed, the Englishman did in Jamaica what he has so often and so well done elsewhere. He organized his colony; he established good local courts, which gained by square treatment the confidence of the blacks. The judges of such courts were Englishmen. The English ruler also provided a good country constabulary, in which native blacks also found service, and in which they could exercise authority over other blacks. Black men, in other words, were trained, under English management, of course, to police black men. A sound civil service was also organized; and in that educated negroes found in due time their place, while the chiefs of each branch of the service were and are, in the main, Englishmen. The excise and the health services, both of which are very highly developed, have brought the law near to the life of the humblest negro, in ways which he sometimes finds, of cotirse, restraining, but which he 
also frequently finds beneficent. Hence he is accustomed to the law; he sees its ministers often, and often, too, as men of his own race; and in the main, he is fond of order, and learns to be respectful toward the established ways of society. The Jamaica negro is described by those who know him as especially fond of bringing his petty quarrels and personal grievances into court. He is litigious just as he is vivacious. But this confidence in the law is just what the courts have encouraged. That is one way, in fact, to deal with the too forward and strident negro. Encourage him to air his grievances in court, listen to him patiently, and fine him when he deserves fines. That is a truly English type of social pedagogy. It works in the direction of making the negro a conscious helper toward good social order.

Administration, I say, has done the larger half of the work of solving Jamaica's race-problem. Administration has filled the island with good roads, has reduced to a minimum the tropical diseases by means of an excellent health-service, has taught the population loyalty and order, has led them some steps already on the long road "up from slavery," has given them, in many cases, the true self-respect of those who themselves officially coöperate in the work of the law, and it has done this without any such result as our Southern friends nowadays conceive when they think of what is called "negro domination." Administration has allayed ancient irritations. It has gone far to offset the serious economic and tropical troubles from which Jamaica meanwhile suffers.

Yes, the work has been done by administration,-and by reticence. For the Englishman, in his official and governmental dealings with backward peoples, has a great way of being superior without very often publicly saying that he is superior. You well know that in dealing, as an individual, with other individuals, trouble is seldom made by the fact that you are actually the superior of another man in any respect. The trouble comes when you tell the other man, too stridently, that you are his superior. Be my superior, quietly, simply showing your superiority in your deeds, and very likely I shall love you for the very fact of your superiority. For we all love our leaders. But tell me that I am your inferior, and then perhaps I may grow boyish, and may throw stones. Well, it is so with races. Grant then that yours is the superior race. Then you can afford to say little about that subject 
in your public dealings with the backward race. Superiority is best shown by good deeds and by few boasts.

\section{IV}

So much for the lesson that Jamaica has suggested to me. The widely different conditions of Trinidad suggest, despite the differences, a somewhat similar lesson. Here also there are great defects in the social order; but again, our Southern race-problem does not exist. When, with such lessons in mind, I recall our problem, as I hear it from my brethren of certain regions of our Union, I see how easily we can all mistake for a permanent race-problem a difficulty that is essentially a problem of quite another sort. Mr. Thomas Nelson Page in his recent book on the "Southerners' Problem" speaks, in one notable passage, of the possibility which he calls Utopian, that perhaps some day the negro in the South may be made to coöperate in the keeping of order by the organization under State control of a police of his own race, who shall deal with blacks. He even mentions that the English in the East Indies use native constabulary. But this possibility is not Utopian. When I hear the complaint of the Southerner, that the race-problem is such as constantly to endanger the safety of his home, I now feel disposed to say: "The problem that endangers the sanctity of your homes and that is said sometimes to make lynching a necessity, is not a race-problem. It is an administrative problem. You have never organized a country constabulary. Hence, when various social conditions, amongst which the habit of irritating public speech about race-questions is indeed one, though only one, condition, have tended to the producing and to the arousing of extremely dangerous criminals in your communities, you have no adequate means of guarding against the danger. When you complain that such criminals, when they flee from justice, get sympathy from some portion of their ignorant fellows and so are aided to get away, you forget that you have not first made your negro countryman familiar with, and fond of, the law, by means of a vigorous and well-organized and generally beneficent administration constantly before his eyes, not only in the pursuit of criminals, but in the whole care of public order and health. If you insist that in some districts the white population is too sparse or too poor, or both, to furnish an efficient country constabulary con- 
stantly on duty, why, then, have you not long since trained black men to police black men? Sympathy with the law grows with responsibility for its administration. If it is revolting to you to see black men possessed of the authority of a country constabulary, still, if you will, you can limit their authority to a control over their own race. If you say all this speech of mine is professorial, unpractical, Utopian, and if you still cry out bitterly for the effective protection of your womankind, I reply merely, look at Jamaica. Look at other English colonies.

In any case, the Southern race-problem will never be relieved by speech or by practices such as increase irritation. It will be relieved when administration grows sufficiently effective, and when the negroes themselves get an increasingly responsible part in this administration in so far as it relates to their own race. That may seem a wild scheme. But I insist: It is the English way. Look at Jamaica, and learn how to protect your own homes.

I have reviewed two very different lessons which I have recently had brought home to me regarding race-problms. What is there which is common to these two lessons? Is it not this: In estimating, in dealing with races, in defining what their supposedly unchangeable characteristics are, in planning what to do with them, we are all prone to confuse the accidental with the essential. We are likely to take for an essential race-characteristic what is a transient incident, or a product of special social conditions. We are disposed to view as a fatal and overwhelming race-problem what is a perfectly curable accident of our present form of administration. If we are indeed of a superior race ourselves, we shall, however, best prove the fact by learning to distinguish the accidental from the essential in our relations with other races. I speak with no lack of sympathy for the genuine and bitter trials of our Southern brethren when I say that I suppose the mistake which I now point out, the mistake of confusing the essential and the accidental, is the mistake that they are now making in many of their sincerest expressions of concern over their race-problem.

So much for the two lessons that have led me to the present discussion. But now let me pass to a somewhat wider view of raceproblems. Let me ask a little more generally, What, if anything, can be known to be essential about the characteristics of a race of men and consequently an essentially important consideration in our dealings with alien races? Speaking so far as we can, apart 
from prejudice, what can we say about what it is which distinguishes the various races of men from one another?

\section{V}

The term "race" is popularly used in a very vague way. The newspapers not long ago said, during trouble in Poland, that the Russian soldiers then in Warsaw showed "race-antipathy" in their conflicts with the people. We all know, however, that the mutual hatred of Russians and Poles is due mainly to political and to religious causes. Frenchmen of the northern provinces, who are anthropologically wholly indistinguishable, as Professor Ripley tells us, from the inhabitants of many western German districts, still have what they call a "race-antipathy" for the men across the border. Thus almost any national or political or religious barrier, if it is old enough, may lead to a consciousness of difference of race. On the other hand, there are, of course, unquestionable physical varieties of mankind, distinguished by well-known physical contrasts. But the anthropologists still almost hopelessly disagree as to what the accurate classification of these true races may be. Such a classification, however, does not concern us here. We are now interested in the minds of men. We want to know what the races of men are socially good for. And not in the study of skulls or of hair, or of skin color, and not in the survey of all these bewildering complications with which physical anthropology deals, shall we easily find an answer to our more practical questions, viz., to our questions regarding the way in which these various races of men are related to the interests of civilization, and regarding the spirit in which we ought to estimate and practically to deal with these racial traits of mankind.

For after all, it is a man's mind, rather than his skull, or his hair, or his skin, that we most need to estimate. And if hereupon we ask ourselves just how these physical varieties of the human stock, just how these shades of color, these types of hair, these forms of skull, or these contours of body, are related to the mental powers and to the moral characteristics of the men in question, then, if only we set prejudice wholly aside, and appeal to science to help us, we find ourselves in the present state of knowledge almost hopelessly at sea. We know too little as yet about the natural history of the human mind, our psychology is far too infantile a 
science, to give us any precise information as to the way in which the inherited, the native, the constitutional aspects of the minds of men really vary with their complexions or with their hair. Yet that, of course, is just what we most want to know. It is easy to show that an Australian is just now far below our mental level. But how far is his degradation due to the inherited and unchangeable characters of his race, and how far to his long struggle with the dreary desert? How far is he, as we now find him, a degenerate, whose ancestors were on some far higher level: In other words, is his type of mind a true variety of the human mind, inbred and unchangeable? How far is it, so to speak, a mere incident? Upon what level were the minds of our own ancestors in the early stone age of Europe? How did their minds then compare with the minds of those ancestors of the Australian who were then their contemporaries? Who shall answer such questions? Yet just such questions we should have to answer before we could decide upon the true relations of race and of mind.

To be sure, anthropology has made a beginning, and a very important beginning, in the study of the mental types of primitive man. By various comparative and archæological methods we can already learn a good deal about the minds of our own ancestors. We can also study various races as they are to-day. We know, about the early stages of human culture, far more than we knew a little while since. But one result may forthwith be stated regarding what we have so far learned concerning the early history of the human mind, whether it is the mind of our ancestors, or of other races. Of course, we cannot doubt that, just as now we widely differ in mental life, so always there must have been great contrasts between the minds of the various stocks of men. No doubt, if the science of man were exact, it would indeed include a racepsychology. But my present scepticism concerns the present state of science, and the result of such study as we have yet made of the racial psychology of man is distinctly disappointing to those who want to make their task easy by insisting that the physical varieties of mankind are in our present state of knowledge sufficient guides to an interpretation of the whole inner contrast of the characters and of the mental processes of men. For what anthropology thus far shows us is, that, so soon as you go back beyond those stages of cultivation where history is possible, and so soon a you view men as they are apart from the higher culture-well, then, all men, so 
far as we can yet study them, appear to us not, of course, the same in mind, but yet surprisingly alike in their minds, in their morals, and in their arts. Widely as the primitive men differ, in certain broad features they remain, for our present knowledge, notably similar. And these common features are such as are by no means altogether flattering to our racial pride, when we think that our own ancestors, too, were, not very long since, comparatively, primitive men like the rest.

All the more primitive men, namely, are largely alike in the grossness and in the unpromising stupidity of their superstitions, and in their moral defects and virtues. Very many of them, belonging to the most various races, resemble one another in possessing customs which we now, for the most part, profoundly abhor, and which we are at present prone to view as characteristic of essentially debased minds. Such customs as cannibalism, or as human sacrifice, or as the systematic torturing of prisoners of war, such horrors as those of the witchcraft from whose bondage Europeans escaped only since the seventeenth century-such things, I say, are characteristic of no one race of men. To surround one's life with a confused mass of spiritual horrors, to believe in ghosts, or in vampires, in demons, in magic, in witchcraft, and in hostile gods of all sorts, to tangle up one's daily activities in a net of superstitious customs, to waste time in elaborate incantations, to live in fantastic terrors of an unseen world, to be terrified by tabus of all kinds, so that numerous sorts of useful deeds are superstitiously forbidden, to narrate impossible stories and believe in them, to live in filth, to persecute, to resist light, to fight against progress, to be mentally slothful, dull, sensuous, cruel, to be the prey of endless foolishness, to be treacherous, to be destructivewell, these are the mental traits of no one or two races of men. These are simply the common evil, traits of primitive humanity, traits to which our own ancestors were very long ago a prey, traits against which civilized man has still constantly to fight. Any frenzied mob of civilized men may relapse in an hour to the level of a very base savagery. All the religions of men, without exception, and however lofty the heights that they have since climbed, appear to have begun with much the same chaos of weird customs and of unreasonable delusions. Man's mental burdens have thus been, in all races, of very much the same sort, except, to be sure, that civilization, side by side with the good that it has created, has 
invented some new mental burdens, such as our increasing percentage of insanity in recent times illustrates.

The souls of men, then, if viewed apart from the influences of culture, if viewed as they were in primitive times, are by no means as easy to classify as the woolly-haired and the straight-haired races at first appear to be. If you study the thoughts of the various peoples, as the anthropologist Bastian has loved to mass them together in his chaotic and learned monographs, or as Fraser has surveyed some of them in his "Golden Bough," well, these primitive thoughts appear, in all their own chaos, and in all their vast varieties of detail, to be the outcome not of racial differences so much as of a few essentially human, although by no means always very lofty, motives. These fundamental motives appear, with almost monotonous regularity, in the superstitions, the customs, the legends, of all races. Esquimaux and Australians, negroes and Scotch Highlanders of former days, ancient Japanese and Hindoos, Polynesians and early Greeks,-all these appear side by side, in such comparative studies of the primitive mind of man, side by side as brothers in error and in ignorance, so soon as you proceed to study by the comparative method their early magic, their old beliefs, their early customs. Yet only by such a study could you hope to distinguish what really belongs to the mind of a race of men, as distinct from what belongs to culture.

If, then, it is the mind and the heart of man that you really want to know, you will find it hard, so soon as you leave civilization out of account, to tell what the precise meaning of the term "race of men" is, when that term is conceived as characterizing a distinct hereditary variety of human mental constitution. A race-psychology is still a science for the future to discover.

Perhaps, however, as you may say, I have not been just, in this very summary statement, to what, after all, may prove to be the best test of the true racial differences amongst the various types of the human mind. Some races, namely, have proved themselves to be capable of civilization. Other races have stubbornly refused civilization, or have remained helplessly degraded even when surrounded by civilization. Others still have perished at the first contact with civilization. The Germanic ancestors of the present western Europeans were barbarians, although of a high type. But when they met civilization, they first adopted, and then improved it. Not so was it with the Indians, with the Polynesians. Here, then, 
is the test of a true mental difference amongst races. Watch them when they meet civilization. Do they show themselves first teachable and then originative? Then they are mentally higher races. Do they stagnate or die out in the presence of civilization? Then they are of the lower types. Such differences, you will say, are deep and ineradicable, like the differences between the higher and the lower sorts of individual men. And such differences will enable us to define racial types of mind.

I fully agree that this test is an important one. Unfortunately, the test has never been so fairly applied by the civilized nations of men that it can give us any exact results. Again, the facts are too complex to be estimated with accuracy. Our Germanic ancestors accepted civilization when they met with it. Yes, but they met civilization under conditions peculiarly favorable to their own education. They had been more or less remotely influenced by its existence, centuries before they entered the field of history. When they entered this field, they met civilization first as formidable foes; they were long in contact with it without being themselves enslaved; and then later, in numerous cases, they met civilization as conquerors, who, in the course of their very efforts to conquer, found thus the opportunity and later something of the leisure to learn, and who had time to discover by centuries of hard experience, how great were the advantages the cultivation of the Roman empire had to offer them. But suppose that Cæsar in the first century B.c. had already had the opportunity to undertake the civilization of Germany by means of our own modern devices. Suppose that he had then possessed unlimited supplies of rum, of rifles, and of machine guns. Suppose in brief that, by the aid of such gentle arts as we now often use, he had very greatly abbreviated the period of probation and of schooling that was open to the German barbarians to learn the lessons that the cultivated peoples had to teach. Suppose that Roman syndicates had been ready to take possession, at once, of the partly depopulated lands of the north, and to keep the few surviving natives thenceforth in their place, by showing them how cultivated races can look down upon savage folk. Well, in that case, the further history of civilization might have gone on without the aid of the Germanic peoples. The latter would then have quickly proved their natural inferiority once for all. They would have furnished one instance more for the race-partisans to cite in order to show how incapable the 
lower races are of ascending from barbarism to civilization. Dead men not only tell no tales; they also, strange to say, attend no schools, and learn no lessons. And hereby they prove themselves in the eyes of certain students of race-questions to have been always of a much lower mental type than the cultivated men who killed them. Their surviving descendants, if sufficiently provided with the means of corruption, and if sufficiently down-trodden, may remain henceforth models of degradation. For man, whatever his race, is an animal that you unquestionably can debase to whatever level you please, if you only have power, and if you then begin early enough, and devote yourself persistently enough to the noble and civilized task of proving him to be debased.

I do not doubt, then, that some races are more teachable than others. But I do very much doubt our power to estimate how teachable a race is, or what can be made of them, or what hereditary mental powers they have until we have given them centuries of opportunity to be taught. Fortune and the defects of the Roman Empire gave to the Germanic peoples an extraordinary opportunity to learn. So the world found out how teachable they were. Let their descendants not boast unduly until they, too, have given to other races, not indeed the opportunities of conquerors, but some equal opportunity to show of what sort of manhood they are capable.

Yet, you may insist, civilization itself had an origin. Were not the races that first won civilized rank superior in mental type to those that never showed themselves capable of such originality? Well, I reply, we do not know as yet precisely where, and still less how, civilization originated. But this seems clear, viz.: first, that physical environment and the forms of social aggregation which this environment determined, had a very great share in making the beginnings of civilization possible; while, secondly, whatever part race-qualities played in early civilization, certainly no one race has the honor of beginning the process. Neither Chinese nor Egyptian, neither Caucasian nor Mongol, was the sole originator of civilization, The African of the tropical swamps and forests, the Australian of the desert, the Indian of our prairies, was sufficiently prevented by his physical envirnoment from being the originator of a great civilization. What each of these races would have done in another environment, we cannot tell. But the Indian of Central America, of Mexico, and of Peru, shows us that race alone did not predetermine how remote from the origination 
of a higher civilization a stock must needs remain. Chinese civilization, and, in recent times, Japanese civilization, have shown us that one need not be a Caucasian in order to originate a higher type of wisdom.

In brief, then there is hardly any one thing that our actual knowledge of the human mind enables us to assert, with any scientific exactness, regarding the permanent, the hereditary, the unchangeable mental characteristics which distinguish even the most widely sundered physical varieties of mankind. There is, to be sure, one exception to this rule, which is itself instructive. It is the case where we are dealing with physical and social degeneracy, the result of circumstances and of environment, and where such degeneracy has already gone so far that we have before us highly diseased human types, such as can no longer be reclaimed. But such types are not racial types. They are results of alcohol, of infection, or in some instances, of the long-continued pressure of physical environment. In such cases we can sometimes say, Here is a hopelessly degraded stock of men. But, then, civilization can create such stocks, out of any race of men, by means of a sufficient amount of oppression and of other causes of degradation, if continued through generations.

No race of men, then, can lay claim to a fixed and hereditary type of mental life such as we can now know with exactness to be unchangeable. We do not scientifically know what the true racial varieties of mental type really are. No doubt there are such varieties. The judgment day, or the science of the future, may demonstrate what they are. We are at present very ignorant regarding the whole matter.

\section{VI}

What, then, in the light of these considerations, is there which can be called fundamentally significant about our numerous modern race-problems? I answer, scientifically viewed, these problems of ours turn out to be not so much problems caused by anything which is essential to the existence or to the nature of the races of men themselves. Our so-called race-problems are merely the problems caused by our antipathies.

Now, the mental antipathies of men, like the fears of men, are very elemental, wide-spread, and momentous mental phenomena. 
But they are also in their fundamental nature extremely capricious, and extremely suggestible mental phenomena. Let an individual man alone, and he will feel antipathies for certain other human beings very much as any young child does-namely, quite capriciously-just as he will also feel all sorts of capricious likings for people. But train a man first to give names to his antipathies, and then to regard the antipathies thus named as sacred merely because they have a name, and then you get the phenomena of racial hatred, of religious hatred, of class hatred, and so on indefinitely. Such trained hatreds are peculiarly pathetic and peculiarly deceitful, because they combine in such a subtle way the elemental vehemence of the hatred that a child may feel for a stranger, or a cat for a dog, with the appearance of dignity and solemnity and even of duty which a name gives. Such antipathies will always play their part in human history. But what we can do about them is to try not to be fooled by them, not to take them too seriously because of their mere name. We can remember that they are childish phenomena in our lives, phenomena on a level with a dread of snakes, or of mice; phenomena that we share with the cats and with the dogs, not noble phenomena, but caprices of our complex nature.

Upon the theoretical aspects of the problem which such antipathies present, psychology can already throw some light. Man, as a social being, needs and possesses a vast range of simply elemental tendencies to be socially sensitive when in the presence of other men. These elemental tendencies appear, more or less untrained, in the bashfulness of childhood, in the stage fright of the unskilled, in the emotional disturbances of young people who are finding their way in the world, in the surprises of early love, in the various sorts of anthropophobia which beset nervous patients, in the antipathies of country folk toward strangers, in the excitements of mobs, in countless other cases of social stress or of social novelty. Such sensitiveness may arise in advance of or apart from any individual experience which gives a conscious reason why one should feel thus. A common feature of all such experiences is the fact that one human being finds other human beings to be portentous, even when the socially sensitive being does not in the least know why they should be so. That such reactions have an instinctive basis is unquestionable. Their general use is that they prepare one, through interest in men, to be ready for social training, and 
to be submissively plastic. In milder forms, or upon the basis of agreeable social relations, such instinctive emotions easily come to be moulded into the most fascinating of human interests; and the social life is impossible without this basis of the elemental concerns which man feels merely because of the fact that other men are there in his world. If decidedly intense, however, such instinctively determined experiences are apt, like other intense disturbances, to be prevailingly painful. And since novelty, oddity, and lack of social training on the part of the subject concerned are motives which tend to make such social reflexes intense, a very great number of the cruder and more childish social reactions involve antipathies; for a social antipathy is merely a painful, and so, in general, an overintense, reflex disturbance in the presence of another human being. No light need be thrown, by the mere occurrence of such an antipathy, upon any permanently important social character of the hated object. The chance intensity of the passing experience may be alone significant. And any chance association may serve to secure, in a given case, the intensity of disturbance which makes the object hated. Oddities of feature or of complexion, slight physical variations from the customary, a strange dress, a scar, a too steady look, a limp, a loud or deep voice, any of these peculiarities, in a stranger, may be, to one child, or nervous subject, or other sensitive observer, an object of fascinated curiosity; to another, slightly less stable observer, an intense irritation, an object of terror, or of violent antipathy. The significant fact is that we are all instinctively more or less sensitive to such features, simply because we are by heredity doomed to be interested in all facts which may prove to be socially important. Whether we are fascinated, or horror-stricken, or angry, is, apart from training, largely a matter of the momentary subjective intensity of the disturbance.

But all such elemental social experiences are ipso facto, highly suggestible. Our social training largely consists in the elimination or in the intensification or in the systematizing of these original reactions through the influence of suggestion and of habit. Hence the antipathy, once by chance aroused, but then named, imitated, insisted upon, becomes to its victims a sort of sacred revelation of truth, sacred merely because it is felt, a revelation merely because it has won a name and a social standing.

What such sacred revelations, however, really mean, is proved 
by the fact that the hungry traveller, if deprived of his breakfast long enough, by means of an accidental delay of his train, or the tired camper in the forest, may readily come to feel whatever racial antipathy you please toward his own brother, if the latter then wounds social susceptibilities which the abnormal situation has made momentarily hyperæsthetic.

I have said little or nothing, in this paper, of human justice. I have spoken mainly of human illusions. We all have illusions, and hug them. Let us not sanctify them by the name of science.

For my part, then, I am a member of the human race, and this is a race which is, as a whole, considerably lower than the angels, so that the whole of it very badly needs race-elevation. In this need of my race I personally and very deeply share. And it is in this spirit only that I am able to approach our problem. 